\title{
Analysis of Physical and Chemical Composition of Sweet Orange (Citrus sinensis) Peels
}

\author{
Oyebola O. Olabinjo $^{1 *}$, Agboola S. Ogunlowo ${ }^{1}$, Olabode O. Ajayi ${ }^{2}$, Ayoola P. Olalusi ${ }^{1}$
}

${ }^{1}$ Department of Agricultural and Environmental Engineering, Federal University of Technology, Akure, Ondo State, Nigeria. ${ }^{2}$ Department of Chemistry, Federal University of Technology, Akure, Ondo State, Nigeria.

\begin{abstract}
Sweet orange is one of the most common fruits in the World. The waste generated from the fruits needs to be put into a beneficial use. In this study some physical and chemical properties of the primary waste of sweet orange was investigated. The result showed sweet orange rinds (peels) as the major waste and contains 45-50\% of the total mass of sweet orange fruits. The chemical analysis showed sweet orange rinds to be rich in protein of $7.15 \%$ and crude fibre of $12.79 \%$ which can be used as ingredients in processed food. These uses will promote sustainable disposal of orange rinds.
\end{abstract}

Keywords-Orange rinds, proximate analysis, protein, crude fibre.

\section{INTRODUCTION}

Citrus (citrus spp) is one of the most abundant fruit crops with World production estimated at 115 million tons per year. Citrus is a large family whose dominant members include sweet oranges (Citrus sinensis), tangerines/mandarin (Citrus reticulata), lemon (Citrus limon), limes (several species) and grape fruits (Citrus paradis). Citrus fruits are notable for their fragrance, partly due to flavonoids and limonoids contained in the rinds (Manthey, 2004). Also, citrus fruits and juices are important sources of bioactive materials including antioxidants such as ascorbic acid, flavonoids and phenolic compounds that are important to human nutrition (Kamran et al., 2009).Citrus fruits are good source of folic acid, vitamin B (thiamine), potassium, phosphorus, calcium, iron, magnesium, sodium and sulphur (Nagy et al., 2007).

The endocarp is rich in soluble sugar and contains significant amounts of vitamin C, pectin, fibres, different organic acids and potassium salt which give the fruits its characteristic "citrus flavour" (Ezejioforet al., 2011).

Africa produces 3,741,000 tonnes of varieties of citrus fruits of which Nigeria contributes 3,240,000 tonnes (FAO, 2004). Nigeria produces $3 \%$ of fresh citrus in the World (FAO, 2004). The rinds (peels) obtained from the pericarp of these fresh fruits are available in large quantities during the citrus season thereby constituting environmental problems since it is not being put into any productive use. The production of citrus fruits in Nigeria is significant, with heavy direct consumption due to few and small capacity processing industries to convert the fruit to juice, concentrate and canned fruit.

The inability of the few and small capacity processing industries to convert the fruit juice and concentrate has led to the generation of wastes. Waste is anything in a ruined or devastated condition (merriamwebster). It can also be defined as any unavoidable material resulting from an activity, which has no immediate economic demand and which must be disposed of (NISP, 2003). Physical properties are important in many problems associated with the design of machines and the analysis of the behaviour of the product during agricultural processing such as extraction of phytochemicals. Physical characteristics of agricultural products are the most important parameters for determination of proper standards to design of grading, conveying, processing, and packaging systems (Tabatabaeefar, and Rajabipour, 2005, Karimiet al., 2009). The food industry has shown a special interest in finding uses for citrus industry byproducts. Hence the need to know the physical and nutrient component of the peels.

\section{MATERIALS AND METHODS}

\subsection{Raw material characterization}

Harvested sweet orange was obtained from a fruit and vegetable market centre from a local market in Akure, Ondo State, Nigeria. The samples were selected manually from unripe and overripe fruits, thus providing a uniform samples or fruits of the relatively same ripeness stage. The ripe fruits were processed at the Crop Processing Laboratory of Agricultural and Environmental Engineering, Federal University of Technology Akure. These fruits were washed to remove dirt's and foreign materials from the epicarp. The fruits were peeled with knife to remove epicarp or rind or flavedo or shell.

2.1.1 Physical Properties of Citrus species

a. Weight determination

The weights of the selected agricultural materials were determined using a method described by Varnamkhastiet al. (2007). The materials were randomly selected from each sample into flat plates which were carefully weighed using an electronic balance to an accuracy of $0.01 \mathrm{~g}$. The 
procedure is replicated three times for each sample, and average value was taken and recorded.

b. Volume determination

The volume of the fruits and peels were determined by filling a $250 \mathrm{ml}$ measuring cylinder with $150 \mathrm{ml}$ of water. The whole fruits and peels of each variety (separately) were immersed in the water. The amount of displacement in water was recorded. The procedure is replicated three times and volume was calculated as:

Final volume - Initial volume $=$

Volume of water displaced(1)

$$
\text { Average volume }=\frac{\text { Volume of } \text { water displaced }}{\text { Total number of fruits } / \text { peels }}
$$

\section{c. Oven dried}

The peeled epicarp were dried in an oven with forced air circulation (Marconi MA03515, Piracicaba, BR) at $50^{\circ} \mathrm{C}$ for $54 \mathrm{~h}$. The dried peeled were then crushed in knife mill type (Marconi M340 Piracicaba, BR) and kept in sealed plastic bags in a frost free freezer (BVR 28 GBBNA BRASTEMP, Joinville, BR) at $-22^{\circ} \mathrm{C}$ until its use.

d. Moisture content determination

Thermal drying method was used in the determination of moisture content of the samples.100g of sample were placed in oven at $105 \pm 3{ }^{\circ} \mathrm{C}$ and allowed to dry to a constant weight for 24 hours (Lagha-Benamrouche, S. and Madani, K., 2013). The moisture content (MC) was calculated by expressing the weight loss upon drying a fraction of the initial weight of sample used. The moisture content of the seeds was determined by gravimetric method which determines the mass loss from the sample by drying to constant weight (ASABE STANDARDS, 1993 and AOAC, 2000).

$D M(\%)=\frac{W_{3}-W_{0}}{W_{1}-W_{0}} * 100(3)$
$\% M C_{d b}=100-D M \%(4)$

Where $W_{o}$ is weight of empty crucible

$W_{1}$ is weight of crucible plus sample before drying

$W_{3}$ is weight of crucible plus sample after drying

$\mathrm{DM}$ is dry matter and

$\mathrm{MC}$ is the moisture content

e. Bulk density

The bulk density was determined using the mass to volume ratio. The volume was determined by water displacement method as described by Archimmedes law of floatation. True or real density is the mass of the sample divided by volume and can be calculated using the equation (5):

$P_{r}=\left(\frac{M}{V}\right)\left(k g / m^{3}\right)(5)$

Where,

$\mathrm{P}_{\mathrm{r}}\left(\mathrm{kg} / \mathrm{m}^{3}\right)=$ True density

$\mathrm{M}(\mathrm{kg})=$ dry specimen mass of $300 \mathrm{~g}$
$\mathrm{V}\left(\mathrm{m}^{3}\right)=$ Volume of sample $=$ Volume of water displaced by $300 \mathrm{~g}$ when immersed in water (Archimedes Principle of Floatation.)

f. Relative density

The relative density was determined for the dried sample of sweet orange. A fixed bed of $300 \mathrm{~cm}^{3}$ (extractant) was used as standard volume of the container and the mass was measured in a previously weighed beaker. No separate manual compaction of sample was done. The bulk density was then calculated from the mass of the sweet orange peels and the volume of the container (Saciliket al., 2003).

g. Particle Size analysis of the milled Sweet orange peels Particle size analysis was carried out on the milled peels product from the knife edge mill after comminution. 200g sample was put into a stack employing a seven-frills set of the standard tyler series of size 10-65 mesh and un shaker screens magnetic type (Bertel, Caieiras, Brazil) which help to promote sufficient granulometric distribution of particles. Mass retained (MR) on each sieve sequel to shaking were retrieved. MR $(\mathrm{g})$ is $\%$ of material retained $\operatorname{MR}(D)(\%)=\frac{m m r}{m s} \times 100(6)$

Where MR (D) is mass of material retained in percent $m m r$ is mass of material retained

The milled peels size $(200 \mathrm{~g})$ was determined in a vertical vibrator sieve shaker Tyler series system (Model 1868 Bertel, Caieiras, BR) with sequential openings of 10, 14, $20,28,35,48$, and 65 mesh. The mean particle diameter was determined using the method of ASAE S319.4 (ASAE, 2008) for granulometry.

The diameter measurement of the particles of Orange peels was determined in terms of geometric mean diameter (or median size), geometric standard deviation of log-normal distribution by mass in ten- based logarithm, and geometric standard deviation by mass (ASABE STANDARDS, 2008), A mass retained in cadapeneira was weighed in semi-analytical balance (the 5500 Mars, Sao Paulo, Brazil) and the average diameter of the particles was calculated by the equation

$d_{g w}=\log ^{-1}\left[\frac{\sum_{i=1}^{n}\left(W_{i} \log d_{i}\right)}{\sum_{i=1}^{n} W_{i}}\right]$

$S_{\log }=\left[\frac{\sum_{i=1}^{n} W_{i}\left(\log d_{i}-\log d_{g w}\right)^{2}}{\sum_{i=1}^{n} W_{i}}\right]^{1 / 2}=\frac{S_{i n}}{2.3}$

$S_{g w} \approx \frac{1}{2} d_{g w}\left[\log ^{-1} S_{\log }-\left(\log ^{-1} S_{\log }\right)^{-1}\right]$

(9)

Where $d_{i}$ is nominal sieve aperture size of the $\mathrm{i}^{\text {th }}$ sieve, (mm)

$d_{i+1}$ is nominal sieve aperture size in next larger than $i^{\text {th }}$ sieve (just above the set ), (mm) 
$d_{g w}$ is geometric mean diameter or median size of particles by mass, $(\mathrm{mm})$, or is geometric mean diameter or median size of particles on sieve, $(\mathrm{mm})$ or is $\left(\left(d_{i} X d_{i+1}\right)^{1 / 2}\right.$, which is $d_{i}$

$S_{\text {log }}$ is geometric standard deviation of log-normal distribution by mass in ten-based logarithm, (dimensionless)

$S_{i n}$ is geometric standard deviation of log-normal distribution by mass in natural logarithm, (dimensionless) $S_{g w}$ is geometric standard deviation of particle by mass ,(mm)

$w_{i}$ mass of material retained on the $\mathrm{i}$-th sieve $(\mathrm{g})$

$\mathrm{N}$ is number of sieves +1 (pan

h. Proximate analysis

The proximate compositions of the dried sample were determined using standard methods to know the nutritive properties. All measurements were done in duplicates and values were presented in percentage.

i. Ash content determination

$\%$ ash content $=\frac{\text { weight of ash }}{\text { weight of sample }} \times 100$

(10)

ii. Fat content determination
$\%$ fat content $=$

$\frac{\text { weight of ether soluble material }}{\text { weight of sample }} \times 100$

(11)

iii. Fibre content determination

$\%$ Crude fiber $=\frac{\text { loss of weight }}{\text { weight of sample }} \times 100$ (12)

iv. Protein determination

Protein content of the sample was determined using the Kjeldahl method

v. Carbohydrate determination $\%$ CHO $=100-(\%$ fat $+\%$ ash $+\%$ fiber + $\%$ protein )

\section{RESULTS AND DISCUSSIONS}

3.1 Physical Properties of the Citrus Species

Physical properties are important in many problems associated with the design of machines and the analysis of the behaviour of the product during agricultural processing operations such as extraction of phytochemicals. The summary of the result for all the physical parameters measured were, collated, analysed and presented (Table 1).

Table. 1: Descriptive statistics of sweet orange from Nigeria.

\begin{tabular}{lccc}
\hline \multicolumn{1}{c}{ Citrus species } & \multicolumn{3}{c}{ Sweet orange Nig. } \\
\hline Property & Max & Min & mean \pm St.dev \\
Total mass $(\mathrm{g})$ & 313 & 202.72 & $250.05 \pm 27.10$ \\
Mass of fruit $(\mathrm{g})$ & 280.18 & 177.26 & $213.10 \pm 22.26$ \\
Mass of peel $(\mathrm{g})$ & 55.23 & 73.96 & $32.69 \pm 7.90$ \\
Total volume $\left(\mathrm{cm}^{3}\right)$ & 240 & 85 & $149.43 \pm 39.30$ \\
volume of fruit $\left(\mathrm{cm}^{3}\right)$ & 190 & 64 & $112.25 \pm 31.56$ \\
Volume of peels $\left(\mathrm{cm}^{3}\right)$ & 65 & 12 & $37.18 \pm 13.88$ \\
Bulk density of peel $\left(\mathrm{gcm}^{-3}\right)$ & 2.24 & 0.085 & $0.99 \pm 0.38$ \\
Relative density of dried peels $\left(\mathrm{gcm}^{-3}\right)$ & & & $0.4007 \pm 0.0023$ \\
\hline
\end{tabular}

The mass of orange ranges from 202.72 - $3132 \mathrm{~g}$ with average mass of $250.05 \mathrm{~g}$ Mass of orange peels ranges from 73.96 - $55.23 \mathrm{~g}$ with average mass of $32.69 \mathrm{~g}$ for Nigeria orange. Citrus fruits contains pulp, peels, internal tissues and seeds. Citrus pulp is the solid residue that remains after fresh fruits are squeezed for their juice. It amounts to $50-70 \%$ of the fresh weight of original fruit, contains peels $30-45 \%$, internal tissues of $20-35 \%$ and seeds $0-10 \%$. The result obtained from the peels were lower than the result reported by Sharma et al, (2017) of $50 \%$ of citrus peels.
The bulk density was determined using the mass to volume. Natural bulk density of sweet orange was 0.99 $\mathrm{gcm}^{-3}$ and mean relative density obtained was $0.4007 \pm$ $0.0023 \mathrm{gcm}^{-3}$ for the dried milled sweet orange peels.

The rinds (peels) obtained from the pericarp of citrus is the primary waste and is available in large quantities during the citrus season thereby constituting environmental hazard and pollution to the environment. There is therefore an urgent need to put it into productive use. Figure 1 shows the result of dried orange milled peels from sweet orange. 


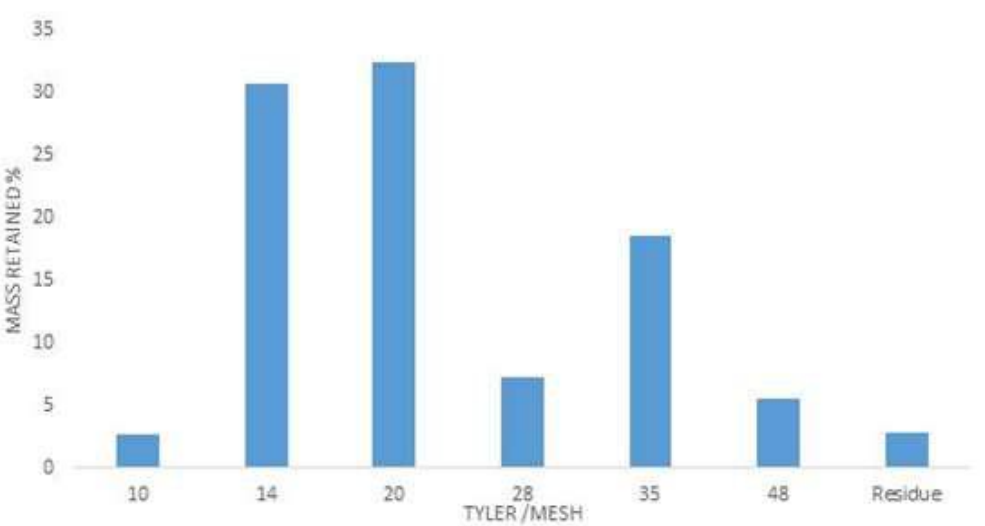

Fig.1: Mass Ground sweet orange peels retained in the sieves

\subsection{Granulometry.}

The milled peels size were determined in a vertical vibrator with six series tyler sieve shaker Tyler series system (Model 1868 Bertel, Caieiras, BR) with sequential openings of $10,14,20,28,35,48$, and 65 mesh with retained percentage mass of $2.62,30.73,32.53,7.21$, $18.59,5.50$ and $2.82 \%$ respectively. The calculated average particle diameter is $0.84 \mathrm{~mm}$ using equation (7). 3.3 Nutrient composition of sweet orange (Citrus Sinensis) rinds
The result of Nutrient composition of dried milled sweet orange peels using proximate analysis is shown in Figure 2.The nutritive composition of sweet orange peels shows crude protein of $7.15 \%$ and crude fibre of $12.7 \%$ (Figure 2 ). The result of crude protein indicating that they could serves as very high protein supplements in addition to contributing to the formation of hormones which controls a variety of body functions such as growth, repair and maintenance of body protein.

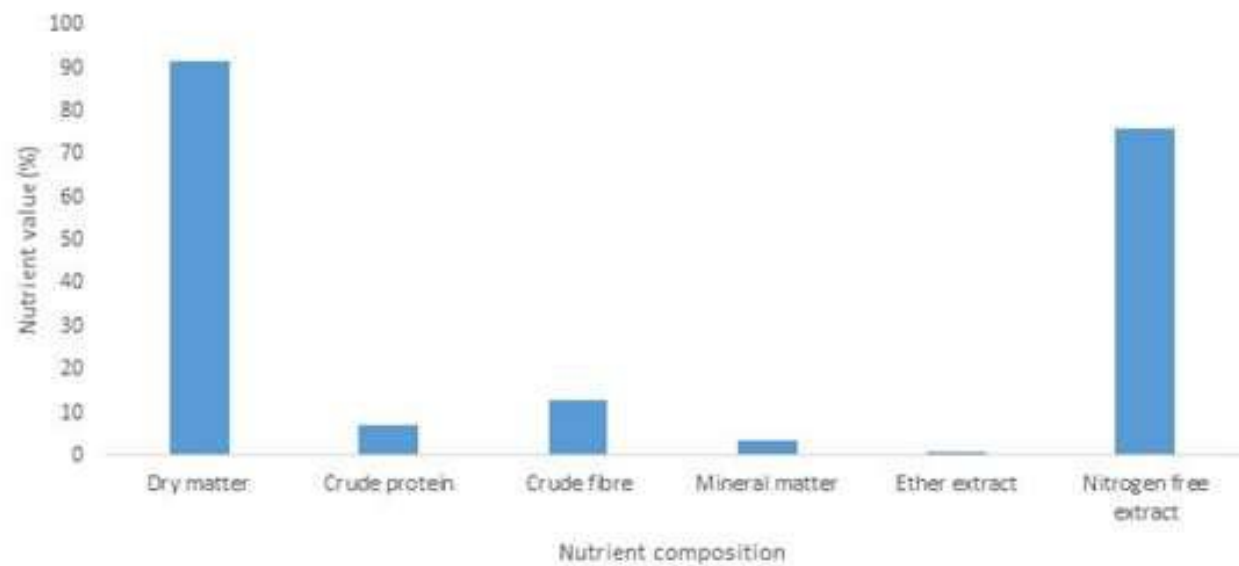

Fig.2: Nutrient composition of sweet ornage (Citrus Sinensis) rind (dry matter basis)

The crude fibre was $12.79 \%$ which also have high value of dietary fibre and higher than the value of water leaf (Talinumtriangulare) of $12 \%$ as reported by Aja et al, 2010. It is also higher than the crude fibre of red bell pepper of $7.4 \%$ as reported by Odewole and Olaniyan, (2016). The result of the crude protein of $7.4 \%$ is higher than the crude protein reported by Awogbemi and Ogunleye (2009) of Fluted pumpkin (Telfairiaoccidentalis) of $2.3 \%$. The result from the nutritive composition showed sweet orange as a promising source of proteins and crude fibre. The average daily requirement of dietary fibre is $21-25 \mathrm{~g}$ per day for women and 30-38 g per day for men (Food and Nutrition
Board, Institute of Medicine, 2001).Nassaret al. (2008) suggested that $15 \%$ of orange peel and pulp could be incorporated as an ingredient in making biscuits, as they are a suitable source of dietary fibre with associated bioactive compounds (flavonoids, carotenoids etc.).It also contains a variety of other nutrients such as proteins, crude fibre and some minerals.

\section{CONCLUSION}

In this study some physical properties and chemical characteristics of sweet orange peels were determined. It showed sweet orange rinds as a primary waste. The study 
provided relevant data which are required for the design of processing equipment for sweet orange rinds.

Based on the chemical composition of sweet orange rinds, the crude fibre and protein of sweet orange rinds can serve as non-caloric bulking agents. They are also capable of offering significant low-cost nutritional dietary supplement to livestock and human beings. Sweet orange rinds could be incorporated as an ingredient in processing of foods and in livestock feeds. These uses will promote sustainable disposal of sweet orange rinds residues.

\section{REFERENCES}

[1] Abad MJ, Bedoya LM, Apaza L, and Bermejo P (2012) The Artemisia L. genus: a review of bioactive essential oils. Molecules 17:2542-2566

[2] Agbetoye L.A.S and Oloye A.O. (2009) Development and Performance Evaluation of a Machine for Removing Essential Oil from Orange Rind. CIGR Section VI International Symposium on Food Processing, monitoring technology in Bioprocesses and Food quality management Potsdam, Germany.

[3] Aja, P.M, OkakaA.N.C,Ibiam U.A., Uraku A.J. and Onu P.N.,(2010) Proximate Analysis of Talinumtriangulare (Water Leaf) Leaves and its softening principle. Pakistan Journal of Nutrition 9 (6) $524-526$.

[4] Akaaimo, D.I. and Raji, A.O. (2006). Some physical and engineering properties of Prosopisafricanaseeds. Biosyst. Eng. 95(2), 197205.

[5] American Society of Agricultural and Biological Engineers, (2008). Method of Determining and Expressing Fineness of Feed. MaterialsbySieving.S319.4,MI.

[6] Aviara, N. A., Oluwole, F. A. and Haque, M. A. (2005). Effect of moisture content on some physical properties of sheanut (Butyrospernumparadoxum). International Agrophysics, 19: 193-198.

[7] Awogbemi,O.and Ogunleye, I.O (2009). Effects of Drying on the Qualities of some Selected Vegetables. IACSIT International Journal of Engineering and Technology, 5: 409-414

[8] Champ, M., Langkilde, A.M., Brouns, F., Kettlitz, B., and Collet, Y., Le, B., (2003). Advances in dietary fibre characterisation. Definition of dietary fibre, physiological relevance, health benefits and analytical aspects. Nutr. Res. Rev. 16, 71-82.

[9] Diao, W.-R., Hu, Q.-P., Zhang, H., and Xu, J.-G. (2014). Chemical composition, antibacterial activity and mechanism of action of essential oil from seeds of fennel (Foeniculum vulgare Mill.). Food Control, $35(1), 109-116$.
[10]Doymaz, I., (2004). Pre-treatment effect on sun drying of mulberry fruits (morusalsa, L.). Journal ofFood Engineering, 65: 205-209.

[11]Esref, I. and Halil, U. (2007): Moisture dependent Physical Properties of White Speckled red Kidney Bean Grains. Journal of Food Engineering, 82: 209216.

[12]Ezejiofor, T.I.N.; Eke, N.V.; Okechukwu, R.I., Nwoguikpe, R.N.; and Duru, C.M., (2011). Waste to wealth: Industrial raw materials potential of peels of Nigerian sweet orange (Citrus sinensis). African Journal of Biotechnology Vol.10 (33), 6257-6264.

[13]FAO, (2004). FAOSTAT data 2005. Food and Agricultural Organisation of the United Nations, 00100, Rome, Italy. February, 2005.

[14]FAO. (2009). Non-farm income from non-wood forest products, by E. Marshall \& C. Chandrasekharan, FAO Diversification booklet No. 12, Rome.

[15]Food and Nutrition Board, Institute of Medicine, (2001). Dietary reference intakes. Proposed definition of dietary fibre. A report of the panel on the definition of dietary fibre and the standing committee on the scientific evaluation of dietary reference intakes. National Academy Press, Washington, DC.

[16] Franco-Vega, A., Ramirez-Corona, Nelly, Palou, E. and Lopez-Malo A., (2016).Estimation of mass transfer coefficients of the extraction process of essential oil from orange peel using microwave assisted extraction. Journal of Food Engineering 170, 135-141.

[17] Fuentes-Zaragoza, E., Riquelme-Navarrete, M.J., Sanchez-Zapata, E., and Perez-Alvarez, J.A., (2010). Resistant starch as functional ingredient: A review. Food Res. Int. 43 (4), 931-942.

[18] Garau, M. C., Simal, S., Rosselló, C., and Femenia. A., (2007). Effect of air-drying temperature on physicochemical properties of dietary fibre and antioxidant capacity of orange (Citrus aurantium v. Canoneta) by-products. Food Chemistry, 104, 10141024

[19] International Association of Analytical Communities, (2000). Official Methods of Analysis of AOAC International. (17th Ed.). Maryland, USA.

[20] Kamran, G., Youcef, G., and Ebrahimzadeh, M. A. (2009).Antioxidant activity, phenol and flavonoid contents of 13 citrus species peels and tissues. Pakistan Journal of Pharmaceutical Sciences 22 (3), 277-281.

[21] Karimi, M., Kheiralipour, K., Tabatabaeefar, A., Khoubakht, G.M., Naderi, M., and Heidarbeigi, K., (2009). The effect of moisture content on physical 
properties of wheat, Pakistan Journal of Nutrition 8 (1): 90-95,

[22] Lagha-Benamrouche, S. and Madani, K., (2013). Phenolic contents and antioxidant activity of orange varieties (Citrus sinensisL. and Citrus aurantiumL. cultivated in Algeria: Peels and leaves. Industrial Crops and Products, 50: 723-730.

[23] Manthey, J.A., (2004). Fractionation of orange peel phenols in ultra-filtered molasses and balance studies of their antioxidant levels. J. Agric. Food Chem. 52:7586-7592

[24] Marin, F. R., Soler-Rivas, C., Benavente-Garcia, O., Castillo, J., and Perez- Alverez, A. J., (2007). By product from different Citrus processes as a sources of customized functional fibres, Food Chemistry 100 (2) $736-741$.

[25] Medoua GN, Egal AA and Oldewage-Theron WH (2009). Nutritional value and antioxidant capacity of lunch meals consumed by elderly people of Sharpeville, South Africa. Food Chem., 115(1): 260264

[26] Nagy, V, Szabo, Z, Mark, L, Deli, J., (2007).Comparative Study on the Carotenoid Citrus. Innovative Food Science and Emerging Technologies, 8:390 - 394.

[27] Nassar AG, AbdEl-Hamied AA and El-Naggar EA. (2008). Effect of citrus by-products flour incorporation on chemical, rheological and organoleptic characteristics of biscuits. World $J$ Agric Sci. 4(5):612-616.

[28] Nigeria Institute of Safety Professionals -NISP (2003). Contractor Employee HSE Training Manual Level 3. Harcourt: ECNEC Ltd.

[29] Odewole, M.M and Olaniyan A.M (2016). Effect of osmotic Dehydration Pre-treatments on Drying rate and post-drying Quality Attributes of Red Bell Pepper(Capsicum annuum). AgricEngInt, CIGR, 18(1): 226-235

[30] Parmar, H. S., and Kar, A., (2008). Medicinal values of fruit peels from Citrussinesis, Punicagranatum and Musa paradisiaca with concentration of glucose, insulin, and thyroid hormones. J. Med. Chem. 11,376-381

[31] Sacilik K, Oztruk R and Keskin R (2003). Some physical properties of hemp seed. Biosystems Eng. 86(4): 191-198.

[32] Sharma, K., Mahato, N, Cho, M.H., and Lee, Y.R., (2017). Converting citrus wastes into value-added products: Economic and environmentally friendly approaches. Nutrition, 34, 29-46.

[33] Simitzis, P. E., Deligeorgis, S. G., Bizelisa, J. A., Dardamania, A., Theodosioua, I., and Fegerosb, K. (2008). Effect of dietary oregano oil supplementation on lamb meat characteristics. Meat Science, 79(2), 217-223.

[34] Sirisomboon, P., Kitchaiya, P., Pholpho, T., and Mahuttanyavanitch, W., (2007). Physica and mechanical properties of Jatropha curcas L. fruits, nuts and kernels. Biosyst. Eng. 97, 201-207.

[35] Sivakumar, D., and Bautista-Banos, S., (2014). A review on the use of essential oils for postharvest decay control and maintenance of fruit quality during storage. Crop Prot. 64, 27-37.

[36] Sivropoulou, A., Papanikolaou, E., Nikolaou, C., Kokkini, S., Lanaras, T. and Arsenakis, M. (1996). Antimicrobial and cytotoxic activities of Origanumessential oils. J. Agric. Food Chem/44, 1202-1205.

[37] Stroshine, R. and D. Hamann, (1995). Physical Harvest/Production Technology, KhonKaen, Properties of Agricultural Materials and Food THAILAND, 21-24 January. Products. West Lafayette, Ind.: Copy Cat.

[38] Tabatabaeefar, A. and Rajabipourm A., (2005). Modeling the mass of apples by geometrical attributes. Sci Horticulture J, 105: 373-382

[39] Tavakoli H., Rajabipour, A., and Mohtasebi S.S. (2009). Moisture-Dependent Some Engineering properties of Soybean grains. Agricultural Engineering Int. The CIGR E-journal. Manuscript PM 1110 Vol. X1.

[40] Varnamkhasti, M. G., Mobli, H., Jafari, A., Rafiee, S., Soltanabadi, M. H., and Kheiralipour, K. (2007). Some engineering properties of paddy (varsazandegi). International Journal of Agriculture and Biology, 9:763-766. 